\title{
'A Sad and Heart-Rending Landscape': Summer 1914 and the Politics of Russia's Wounded
}

\section{PETER WALDRON}

ON 8 August 1914, less than three weeks after the outbreak of war between Russia and Germany, representatives from forty-four Russian cities met in Moscow to discuss the contribution they could make to the war effort. Viktor Brianskii, the Moscow mayor, opened the meeting with a rousing speech. He declared that:

Russia is living through a moment of great historical significance, requiring the full exercise of all our strength. A centuries-old quarrel is being resolved, the question of the superiority of the Slavs or the Teutons, and this issue must be settled once and for all. There cannot, and should not, be any half-hearted resolution of this question. [...] Victory must be total and the Slavs must be victorious, since only they are able to bring Europe permanent and durable peace. ${ }^{1}$

These representatives of Russia's local government organizations greeted the war with enthusiasm, cheering when the text of a telegram to Nicholas II was read out and they, together with their colleagues in the zemstva, took rapid steps to contribute to the Russian war effort. This article will discuss the role of these public organizations during the first months of the war. ${ }^{2}$

Peter Waldron is Professor of Modern History at the University of East Anglia.

I am very grateful to the Wellcome Trust for its generous financial support during the preparation of this article.

1 S"ezd gorodskikh golov v Moskve 8-9 avgusta 1914 goda. Stenograficheskii otchet, Moscow, 1914, p. 2.

2 The wartime role of public organizations has been discussed in Tikhon J. Polner, Russian Local Government during the War and the Union of Zemstvos, New Haven CT, 1930, 
Patriotic enthusiasm for war was evident from its first days. ${ }^{3}$ On 20 July, the Emperor performed the ceremonial duties that marked Russia's entry into the war against Germany. Sitting in the Malachite Room of the Winter Palace in St Petersburg, he signed the formal manifesto announcing the Russian declaration of war and followed this with a speech to the assembled dignitaries of the empire in the palace's Nicholas Hall. 'I solemnly affirm', the tsar asserted, ' that I shall not conclude peace while a single enemy soldier remains on our soil'. Nicholas then appeared on the Winter Palace's central balcony, overlooking Palace Square, where great crowds had gathered carrying the Russian flag and large portraits of the emperor. ${ }^{4}$ Support for the war was very plain when the Duma and State Council gathered on 26 July in the Winter Palace to be addressed by the tsar. Nicholas emphasized the national unity that had been demonstrated in the first days of the war, declaring that 'the enormous surge of patriotic feelings of love and devotion to the throne which has spread like a hurricane across our whole land, shows [...] that our great Mother Russia will bring this [...] war to its desired conclusion'.5 The purpose of the joint sitting of the legislative chambers was to vote credits to provide the government with the financial resources to wage war and none of the political parties represented in the Duma was prepared to vote against this measure. Even the Bolsheviks, the most severe of the government's critics in the Duma, decided to abstain rather than run counter to the prevailing public mood by directly opposing finance for the war. Representatives of other political parties made speeches in which they gave extravagant praise to the national unity that the war had engendered. Rodzianko, the Duma chairman, contended that 'our enemies believed that we were divided by

and Paul P. Gronsky and Nicholas J. Astrov, The War and the Russian Government, New Haven CT, 1929, pp. 131-311. More recent studies include Mark George, 'Liberal Opposition in Wartime Russia: A Case Study of the Town and Zemstvo Unions, 1914-1917', Slavonic and East European Review, 65, 1987, 3, pp. 371-90; V. M. Shevyrin, Vlast' i obshchestvennye organizatsii v Rossii (1914-1917), Moscow, 2003, and A. S. Tumanova, Obshchestvennye organisatsii Rossii v gody Pervoi mirovoi voiny (1914-fevral' 1917 g.), Moscow, 2014.

3 Hubertus F. Jahn, Patriotic Culture in Russia during World War I, Ithaca, NY, 1996, pp. 171-73; I. S. Rozental', 'Obrazovannoe obshchestvo i narod', in Iu. A. Petrov (ed.), Rossiia v gody Pervoi mirovoi vony: ekonomicheskoe polozhenie, sotsial'nye protsessy, politicheskii krizis, Moscow, 2014, pp. 399-413 (pp. 403-04). A more differentiated view is presented in Josh Sanborn, 'The Mobilization of 1914 and the Question of the Russian Nation: A Reexamination', Slavic Review, 59, 2000, 2, pp. 267-89.

4 B. Kolonitskii, 'Tragicheskaia erotika': Obrazy imperatorskoi sem'i v gody Pervoi mirovoi voiny, Moscow, 2010, pp. 73-77.

5 Gosudarstvennaia Duma, Stenograficheskie otchety, sozyv IV, sessia 2, 26 July 1914, p. 2. 
dissension and hostility, whereas all the peoples populating the immense Russian lands have united in one fraternal family once society has been threatened by calamity'. Alexander Kerenskii, a member of the Trudovik party, was applauded from all sides of the Duma when he declared that 'the great power of Russian democracy, alongside all its other strengths, will deliver a decisive rebuff to the enemy' and deputies from the Baltic provinces of the empire - heavily populated by Baltic Germans - assured the Duma that their loyalty to the Russian cause was absolute. ${ }^{6}$

The government took other steps to try to capitalize on the patriotism that the outbreak of war had stimulated. On 19 August, an imperial decree announced that St Petersburg, the imperial capital, was to be renamed Petrograd, a more Russian appellation than its original German-sounding name. The censorship regime imposed at the start of the war meant that there was no discussion of the decision in the Russian press, but there were some indications that the new name was not universally popular, especially since the renaming coincided with the first reports of Russian military defeat by the Germans in East Prussia. Baron Nikolai Wrangel', a noted art critic, wrote in his diary for 19 August that

the dreadful rumours have been confirmed and today's official communiqué talks about serious reverses. Today's imperial order about the renaming of St Petersburg as Petrograd is especially tactless. This is a senseless decision that, above all, clouds the memory of the great man who transformed Russia, but the publication today of the renaming as 'revenge' on the Germans, on the day of our defeat, is extremely inappropriate. [...] The whole city is deeply disturbed and indignant at this tactless trick?

The decision to rename the city was reported to a meeting of the city Duma on 25 August and the Duma members merely noted the change, with no applause following the announcement of the tsar's decision. ${ }^{8}$

The change to the name of the imperial capital possessed great symbolic significance, but a further measure designed to capitalize on the patriotic commitment to war affected Russian society much more directly. On 22 August the tsar issued a decree prohibiting the sale of vodka for the duration of the war. The motivation for imposing prohibition was complex, with some contemporaries viewing it as representing a second emancipation, this time from the slavery of the Ministry of Finance's alcohol monopoly

6 Gosudarstvennaia Duma, Stenograficheskie otchety, 26 July 1914, pp. 11, 29, 31.

7 N. N. Vrangel', Dni skorbi. Dnevnik 1914-1915 godov, St Petersburg, 2001, p. 44.

8 Izvestiia S.-Peterburgskogo gorodskoi dumy, 1914, vol. 196, no. 49, p. 1331. 
over the people of the empire. V. A. Kaigorodov, a member of the Minsk provincial zemstvo, wrote that 'in 1914 Alexander II's mighty grandson has through his grand designs freed the people's soul from the torments of the green serpent'. 9 Temperance was regarded as a means both to promote the effectiveness of Russia's fighting forces, and to ensure that the home front stood firm in its contribution to the war effort. The impact of prohibition on the government's finances was secondary, with the Council of Ministers at its meeting on 9 August merely instructing the Minister of Finance to report on the consequences for the treasury of a prolonged ban on the sale of spirits. ${ }^{10}$ Instead, the government was concerned about the potential for drunkenness among Russia's troops, especially during the initial period of mobilization and among the reserves. Prohibition was a means of strengthening the fighting capacity of Russia's army. ${ }^{11}$ The apparent widespread popular enthusiasm for the war - at least among the urban population - that the government wanted to encourage found expression in the production of large numbers of patriotic cartoons and postcards that supported the Russian war effort, lauding the prowess of Russia's armies and displaying confidence in the outcome of the war. ${ }^{12}$

Russia's local government institutions very quickly showed their enthusiasm to contribute to the war effort. As international tensions sharpened during July 1914, the Moscow city duma wrote to other Russian city dumas suggesting that preparations should be made in case war broke out. The duma identified that rapid medical help for Russia's soldiers was likely to be a central priority, both on the battlefield and in Moscow itself, and it assigned a credit of one million rubles for this, at the same time as opening a fund for donations from other cities. ${ }^{13}$ The outbreak of war on 19 July stimulated Russian local government to vigorous activity. Brianksii, the Moscow mayor, convened a meeting of the Moscow city board and representatives of public organizations in the city on 28 July

9 Artur Mak-Ki, 'Sukhoi zakon v gody pervoi mirovoi voiny: prichiny, kontseptsiia i posledstviia vvedeniia sukhogo zakona v Rossii. 1914-1917 gg.', in Rossiia i pervaia mirovaia voina (Materialy mezhdunarodnogo kollokviuma), St Petersburg, 1999, pp. 147-59 (p. 147).

10 'Osobyi zhurnal soveta ministrov, 9 avgusta 1914 goda', Osobye zhurnaly Soveta ministrov Rossiiskoi imperii. 1914 god., Moscow, 2006, p. 271.

${ }^{11}$ V. B. Aksenov, "Sukhoi zakon" 1914 goda: ot pridvornoi intrigii do revoliutsii', Rossiiskaia istoriia, 2011, no. 4, pp. 126-39 (pp. 129-32); David Christian, 'Prohibition in Russia 1914-1925', Australian Slavonic and East European Studies, 9, 1995, pp. 89-108 (pp. 91-93).

${ }^{12}$ Jahn, Patriotic Culture, pp. 31-50.

${ }_{13}$ Moscow, Tsentral'nyi Gosudarstvennyi Arkhiv Moskvy (TsGAM), f. 179, op. 6o, d. 791, 1l. 1-2. 
to bring some unity to the work of providing for military casualties. Brianskii noted that Moscow's organizations were disunited: the city duma board only had formal links with the Moscow provincial zemstvo and had little knowledge of Moscow's overall readiness to provide help for casualties. ${ }^{14}$ Two days later, on 30 July, a meeting took place in Moscow of representatives from thirty five provincial zemstva to discuss the organization of assistance to wounded soldiers. A further six zemstva were unable to send representatives but conveyed their support, and the meeting was also attended by Nikolai Guchkov, the former mayor of Moscow who now chaired the Moscow municipal social welfare board and the Moscow branch of the Red Cross, and Georgii L'vov, the chairman of the zemstvo organization for the provision of charitable assistance and a prominent figure in Russian political circles. Only the notoriously conservative Kursk zemstvo refused to offer support to the gathering, while the war ministry prohibited representatives of the Don region from taking part. The meeting heard reports from Alexander Samarin, the head of the Russian national Red Cross organization and M. V. Kochergin, the military official responsible for the evacuation of wounded soldiers from the front line. Discussion centred on the establishment of a new national organization to provide assistance to the wounded and the meeting elected L'vov as its head. ${ }^{15}$ This marked the formal foundation of the All-Russian Zemstvo Union. Its function was set out in the second part of its title: it was intended to provide 'assistance to wounded and sick soldiers'.

The following day representatives from zemstvo and municipal organizations in the Moscow military evacuation district met in Moscow and noted the huge difficulties that confronted local government organizations in providing help to organize the transport of the wounded from the battlefield and to provide medical help once they had been evacuated. Existing provision for medical care in the Russian empire was very confused and there was no single central ministerial body that oversaw health matters. Responsibility for health was divided between the Ministries of Internal Affairs and War, while charitable organizations as well as the zemstva themselves also playing a part in providing medical services. ${ }^{16}$ During the 188 os, the prominent doctor Sergei Botkin orchestrated pressure to bring national healthcare provision under a

${ }^{14}$ Moscow, Rossiiskii Gosudarstvennyi Voenno-istoricheskii Arkhiv (RGVIA), f. 12593, d. $1,1.83$.

${ }^{15}$ RGVIA, f. 12564, op. 1, d. 3, ll. 1-5.

16 John F. Hutchinson, Politics and Public Health in Revolutionary Russia, 1890-1918, Baltimore, MD, 1990, pp. 4-5. 
single body, but inter-ministerial rivalry meant that the project came to nothing. Instead, the zemstvo themselves played a more substantial role in the provision of healthcare. ${ }^{17}$ The sheer scale of the task that faced the zemstva and city councils in 1914 was, however, entirely novel for them and very different from both their previous work providing healthcare and the experience of the war with Japan a decade earlier. It was immensely complex and made all the more difficult by the impossibility of predicting the precise circumstances in which the war would develop and the potential numbers of wounded. The meeting heard a report from Kochergin about the planning that had been undertaken for dealing with casualties, and the representatives agreed that they needed to unite their efforts to provide proper help. ${ }^{18}$ The rush of meetings continued on 3 August when a preparatory committee for the new national organization of Russian cities gathered in Moscow. The work to set up a body to bring together Russia's cities ran parallel to the efforts to establish a national zemstvo organization and the preparatory committee agreed to invite the whole committee of the nascent zemstvo union to its first formal congress. ${ }^{19}$

The Moscow-based initiative to promote unity among local government institutions was supported by most of Russia's provincial zemstva and city dumas. Telegrams arrived in Moscow from other cities in the first days of August: the Arkhangel'sk duma regretted that it could not attend the Moscow meeting on 3 August, but reported that it had opened a fifteen-bed hospital to take casualties, while Kazan ' ${ }^{-}$and Vladikavkaz both expressed their support for the new organization. The Ufa city duma held a special meeting on 3 August at which it resolved to take part in the national city union, allocating 15,000 rubles for the purpose, and requesting that the new organization raise the issue of prohibiting the sale of all alcoholic drink during the war. Not every city, however, was as enthusiastic: both the Batum and Vil'na dumas reported that they were unable to discuss the invitation to establish a new national organization due to the circumstances of war and the imposition of martial law. ${ }^{20}$

The Union of Towns came into formal existence at a meeting in Moscow

${ }^{17}$ Samuel C. Ramer, 'The Zemstvo and Public Health', in Terence Emmons and Wayne S. Vucinich, (eds), The Zemstvo: An Experiment in Local Self-Government, New York, 1982, pp. $279-314$.

${ }_{18}$ TsGAM, f. 179, op. 6o, d. 791, 11. 34-42, Zhurnal predstavilelei gorodov i zemstv, prinadlezhashchikh $k$ Moskovskomu Evakuatsionnomu okrugu, po voprosam pomoshchi bol'nym i ranenym voinam, iulia 31 dnia 1914 goda.

19 TSGAM, f. 179, op. 6o, d. 791, 1l. 72-73, Zhurnal predvaritel'nogo komiteta po organizatsii obshche-gorodskogo vserossiiskogo s"ezda.

${ }_{20}$ TsGAM, f. 179, op. 60, d. 791, 11. 53-59, 70. 
on 8 and 9 August. Brianskii's speech set the tone for the gathering, but he did not shy away from recognizing the very difficult consequences that war presented. Brianskii noted that, with millions of men on the battlefield, there would be hundreds of thousands of casualties. Russia must be ready to deal with such large numbers of wounded and there must be unity among the organizations that provided assistance to casualties. He reminded his audience that during the Russo-Japanese war a decade earlier, the zemstva had recognized the importance of working together as a united organization. Now, declared Brianksii, it was the turn of Russia's cities to unite and play their part. ${ }^{21}$ Official permission for the establishment of both unions was given by the Ministry of Internal Affairs on 12 and 16 August, but this was a formality: on 6 August L'vov had met Nicholas II while the tsar was visiting Moscow. Nicholas welcomed the work of the zemstva, and asked L'vov to pass on his good wishes for the success of zemstvo work with the wounded. ${ }^{22}$ The following day the emperor and empress, together with their daughters, visited zemstvo warehouses on Novinskii boulevard, giving a clear sign that the work of local government in support of the war had the stamp of approval from the highest authorities in the empire. ${ }^{23}$ The imperial family's immediate approbation of the way in which the zemstva and city dumas were uniting in support of the war effort gave the new unions very considerable authority throughout the course of the war: even when the government's enthusiasm for the unions diminished during 1915 and 1916, they were able to point to the personal approval of the sovereign for their work. ${ }^{24}$

The way in which the two unions were able to establish themselves so quickly and easily was all the more surprising, given the Russian government's traditional extreme reluctance to countenance any form of organization that brought together the empire's institutions of local government. Ever since zemstva and city dumas had been introduced in the 1860 os and 1870 s during the reign of Alexander II, the St Petersburg government had thwarted almost every attempt by the local government institutions themselves to formulate some type of over-arching organization that united the various provincial, district and municipal bodies. It had

${ }^{21}$ S"ezd gorodskikh golov, pp. 3-4.

22 RGVIA, f. 12564, op.1, d. 3, 1. 19.

${ }^{23}$ Vserossiiskii zemskii soiuz pomoshchi bol'nym i ranenym voinam. Izvestiia glavnogo komiteta, 15 October 1914, p. 10.

${ }^{24}$ For example, in November 1915 the government attempted to prohibit a meeting of the congress of the Union of Zemstvo. L'vov responded by referring to Nicholas II's August 1914 approval of the union's work. RGVIA, f. 12564, op. 1, d. 9, 1. 4. 
only been at times of grave emergency that any form of united action by Russia's local government institutions had been permitted: the Volga famine of the early 1890 s and the Russo-Japanese war of 1904-05 were the only real occasions when the state had permitted concerted action by the zemstva. ${ }^{25}$ It was the exceptional circumstances engendered by the outbreak of a full-scale European war that allowed the zemstva and city dumas to unite: war was unexpected both in its timing and its scale in 1914. The government was taken by surprise both by the onset of war and by the powerful wave of patriotism that took hold of Russia in July and August 1914 and, for a short period, it was caught off balance and was prepared to concede rights to public organizations that it had been loath to permit for the previous half century. The Minister of Internal Affairs, Nikolai Maklakov, recognized this in his submission to a meeting of the Council of Ministers on 25 November when he wrote that 'the war and its surrounding fervour have given rise to a range of phenomena that were unforeseen by existing legislation and have no precedent in our past'. He noted that, once Nicholas II had met L'vov in Moscow on 6 August, the formation of the Zemstvo Union was essentially a fait accompli and there had been no proper consideration of their function or organizational structure when formal permission was given for their formation of the two unions. Maklakov argued that the two bodies were essentially operating beyond the confines of the law and that their position should be regularized. ${ }^{26}$

The two unions were, from their initial formation, woven closely into the fabric of Russian elite political life. The Zemstvo union attracted liberally-minded zemstvo members, and its executive committee included men whose views were largely in the centre and liberal wings of Russian politics. Headed by L'vov, the thirteen members of the committee included Nikolai Guchkov, the brother of the leader of the Octobrist party, Count Vladimir Musin-Pushkin, an elected member of the State Council where he sat with the centre group, Ivan Kanshin, an Octobrist member of the fourth Duma, Count Fedor Uvarov, an elected member of the State Council who had joined the centre-right group, Dmitrii Shchepkin, a senior Duma bureaucrat who had worked as the secretary to the Duma chairman (and who was to perish in the Stalinist purge in 1937). The close relations between the Zemstvo Union and the Union of Towns was shown by the inclusion of two representatives from the urban union on

25 T. I. Polner, Obshchezemskaia organizatsiia na Dal'nem Vostoke, vol. 1, Moscow, 1908, pp. 5-15.

26 'Osobyi zhurnal soveta ministrov, 25 noiabria 1914 goda', Osobye zhurnaly Soveta ministrov Rossiiskoi imperii. 1914 god., Moscow, 2006, pp. 545-46. 
the zemstvo executive committee: Nikolai Astrov, a prominent Kadet who both sat on the Moscow city duma and was also a bureaucrat working in the State Duma, and Mikhail Chelnokov, a leading Kadet who had been a member of the State Duma since $1907 .{ }^{27} \mathrm{~L}^{\prime}$ vov himself was an aristocrat and Tula landowner who had been a member of the Union of Liberation in the first years of the century and was elected to the First and Second State Dumas in 1906 and 1907 where he was close to the Kadet party, although not a formal member of the Duma party. He took a particular interest in the policy of peasant migration to Siberia and in 1912 was nominated as Moscow mayor, but his appointment was rejected by the Ministry of Internal Affairs who believed that his public pronouncements showed antigovernment sentiment. ${ }^{28}$

The Union of Towns was chaired for its first month by Brianksii until, in September 1914, Chelnokov took over at the organization's helm, and its executive committee shared some of the same members as the zemstvo union. Astrov, Guchkov and Shchepkin were members of both bodies, and the Union of Towns committee also included Vladimir KuzminKaravaev, a noted lawyer who had been a member of the first and second State Dumas, before being defeated in elections to the third Duma in late 1907. The Union of Towns had strong connections with the Kadet party, but when Chelnokov was elected as Moscow mayor in September 1914 and took over as chairman of the Union of Towns, he left the Kadet Duma party, arguing that in his new position he should stand apart from party politics. ${ }^{29}$ The leadership of both unions was intimately bound up with the political structures that had come into being in Russia after the 1905 October Manifesto. Politics - along with family ties - bound together the men who ran the organizations, but it would be a mistake to see the unions simply as offshoots of the Russian political parties that espoused centrist and liberal views. The unions recognized that they had to represent the full breadth of opinion in Russian local government and could not adopt narrowly partisan approaches to politics. Only a single provincial zemstvo - Kursk - stood apart from the zemstvo union, while the Union of Towns grew dramatically after its formation. In September 1914, the union counted 195 towns among its members, but by January 1915 it had expanded to represent 428 municipalities and in September 1917 it included 630 towns - some 75 per cent of the towns of the empire outside enemy

${ }^{27}$ Lichnyi sostav uchrezhdenii vserossiiskogo zemskogo soiuza, Moscow, 1915, p. 4.

${ }^{28}$ T. I. Polner, Zhiznennyi put' kniazia Georgiia Evgenevicha L'vova. Lichnost'. Vzgliady. Usloviia deiatel'nosti, Moscow, 2001, pp. 241-45.

${ }^{29}$ Shevyrin, Vlast' i obshchestvennye, pp. 42-43. 
occupied territory. ${ }^{30}$ Astrov, one of the most vocal and radical members of the leadership of the Union of Towns, wrote that

the union never promoted the policy of one or other political party. We were free from party directives. There was a tacit agreement between the members of the Union and the political parties to which we belonged. In our political pronouncements we expressed the attitudes of the social groups that were united by the Union of Towns and formulated these ideas. $^{31}$

The formation of the two unions was not prompted by political parties but, given the relatively small number of men who were active in Russian national and local political circles, it was unsurprising that the two unions were led by men who had played a significant part in the legislative institutions that had been created in 1905 and 1906. Enthusiasm for the work of the unions was generated by the circumstances of the outbreak of war, but it also reflected the frustrations of liberal and centre politicians at the way in which they had been marginalized in the Duma and the State Council. The brusque curtailment of the national Duma franchise in June 1907, and the subsequent reduction in liberal representation in the Third and Fourth Dumas, dashed the expectations of an opportunity for open political work that had been created in October 1905. The Kadet party, in particular, had been hounded by the Russian government after its call for civil disobedience in the 1906 Vyborg Manifesto and its members felt deeply frustrated by the way in which Russia's constitutional politics had developed. Ariadna Tyrkova, a prominent Kadet, noted how interest in Kadet party politics had declined by 1914, so that 'only half a dozen people turned up to party congresses' and how Kadet members saw it as desirable 'to intensify their practical work in the public organizations in every possible way'. ${ }^{2}$ The centrist Octobrist party had also ossified and almost ceased its extra-parliamentary activity. ${ }^{33}$ The formation of the two unions aimed at giving assistance to Russia's wounded provided a practical outlet for the energies of Russia's moderate and liberal politicians and, moreover, involved them in work that was irreproachable in its aims and content.

30 Tumanova, Obshchestvennye organisatsii Rossii, p. 99.

${ }^{31}$ Ibid., p. 100.

32 Protokoly Tsentral'nogo komiteta $i$ zagranichnykh grupp Konstitutsionnodemokraticheskoi partii, 1905-ser. 1930-kh gg., 6 vols, Moscow, 1994-99, vol. 2, pp. 364-66.

33 F. A. Gaida, Liberal'naia oppositsiia $n$ putiakh k vlasti (1914-vesna 1917 g.), Moscow, 2003 , p. 48. 
The war on Russia's western borders accelerated very quickly. The policy agreed between the French and Russian military before the outbreak of war assumed that the brunt of the initial German attack would come in Western Europe and that, therefore, the Russians must open an offensive early in the war to distract the Germans from their onslaught on the French. Russian troops crossed the border into East Prussia on 4 August, the sixteenth day of the war, and two Russian armies were ordered to entrap the German forces in a pincer and force them to retreat. The Russian strategy proved to be wholly unsuccessful: the forested lakeland of East Prussia was difficult terrain for an offensive, while Russian command was at times chaotic and the actions of the Russian forces were poorly coordinated. The railway network on the Russian side of the border was weakly developed, making it difficult for the Russians to move their troops quickly and easily. Within two weeks, the Russian armies had been routed by the Germans: the Second Army was encircled by the Germans and its commander, General Samsonov, committed suicide. The battle of Tannenberg was followed by a German advance that pushed Russian troops back across the border in the battle of the Masurian Lakes, bringing an ignominious end to the first Russian actions of the war. ${ }^{34}$ Russia fared much better against the Austro-Hungarian armies in Galicia and was able to seize the city of L'vov on August 21, but only at the cost of very heavy casualties. More than 100,000 Russian soldiers were taken prisoner by the Germans in East Prussia and 40,000 were imprisoned to the Austrians in Galicia, but these figures were dwarfed by the numbers of men who were killed and wounded. Some 100,000 Russian troops lost their lives in the battles of 1914, and more than 210,00o were wounded between the outbreak of war and early October. ${ }^{35}$

The Russian army had made substantial preparations for dealing with casualties, drawing on the experience of the war with Japan a decade earlier. There was an official recognition that the numbers of casualties in a major European war would far exceed anything seen in the wars of the nineteenth century, and that it was therefore essential to evacuate the wounded as quickly as possible from the battlefield. The Russo-Japanese war had shown that it was vital to have a cohesive set of organizations dealing with the wounded since, as the General Staff noted 'the absence

\footnotetext{
${ }^{34}$ M. V. Os'kin, Istoriia pervoi mirovoi voiny, Moscow, 2014, pp. 100-07; N. Stone, The Eastern Front 1914-1917, London, 1998, pp. 59-69.

${ }_{35}$ RGVIA, f. 2003, op. 2, d. 426, 1. 7. B. Ts. Urlanis, Istoriia voennykh poter'. Voiny $i$ narodonaselenie Evropy. Liudskie poteri vooruzhennykh sil Evropeiskikh stran v voinakh XVII-XX vv. (istoriko-statisticheskoe issledovanie), St Petersburg, 1994, pp. 142-46.
} 
of coordination and communication in the activity of [evacuation] institutions was a serious defect in the evacuation work in the war. ${ }^{36}$ The military planning for dealing with the wounded in the event of a war was based on dividing Russia into two zones. The area closest to the front line, west of a line from Lake Ladoga in the north, through Smolensk to Azov in the south was under the exclusive control of the military authorities, while civilian bodies were responsible for the rest of the empire. Military planning envisaged that only the army would work in the western areas, and that public organizations, while they could offer widespread material help, would be restricted to playing a role outside the military zone. ${ }^{37}$ The evacuation administration of the General Staff was to take charge of the process and the wounded would be taken to first aid points close to the battlefield and, after basic treatment, be transported by hospital trains to distribution centres in cities in the Russian interior where they would spend a few days having their injuries assessed. ${ }^{38}$ The least seriously injured would then be moved to other cities where they would be under the care of public organizations. The military understood that there would be significant demand for hospital trains and, when the chairman of the Russian Red Cross addressed representatives from towns in the Moscow evacuation district on 31 July, he indicated that the army would welcome assistance from public organizations in equipping trains. The civilian ministries had also considered their needs in the case of war in the wake of the conflict with Japan, and in 1908 the Council of Ministers had requested each ministry to report on the issues that faced it in preparing a plan for national defence. None of the ministries mentioned the need to prepare for caring for large numbers of wounded, indicating the lack of responsibility that they each felt for providing medical services across the empire. ${ }^{39}$

Even though the Chief of the General Staff had acknowledged in a 1911 report that the scale of casualties would be much greater than during previous wars, the military continued to base their calculations of the likely numbers of wounded on the experience of previous conflicts. The general staff believed that, with its knowledge of the size and composition of the armies on the battlefield, it could predict the numbers of casualties

36 'Doklad nachal'nika general'nogo shtaba voennomu ministru, 21 maia 1911', Sanitarnaia sluzhba russkoi armii v voine 1914-1917 gg. (Sbornik dokumentov), Kuibyshev, 1942 (hereafter Sanitarnaia sluzhba), pp. 48-49.

37 Laurie S. Stoff, Russia's Sisters of Mercy and the Great War: More than Binding Men's Wounds, Lawrence, KS, 2015, pp. 48-49.

${ }^{38}$ I. B. Belova, Pervaia mirovia voina i rossiiskaia provintsiia 1914-fevral' 1917, Moscow, 2011, p. 130.

39 St Petersburg, Rossiiskii Gosudarstvennyi Istoricheskii Arkhiv, f. 1276, op. 4, d. 130, 11. 430-46. I am grateful to Dominic Lieven for this reference. 
very precisely and it estimated that Moscow - at the centre of the Russian railway network and thus likely to take the bulk of wounded - would receive between 35,000 and 70,000 casualties each month. ${ }^{40}$ Speaking in early August, Samarin - the head of the Russian Red Cross - was even more precise in his estimates of the numbers of wounded that would require treatment. The general staff had identified seven cities as distribution centres for casualties and had calculated that there would be a total of 119,700 wounded men each month, allocating 3,00o to Vologda, 11,200 to Tver', 25,00o to Rzhev, 18,00o to Viazama, 26,500 to Briansk, 17,500 to Kursk and 18,500 to Khar ' kov. Wounded men would be transferred from these towns to treatment points, with Moscow taking the heaviest load of 35,000 men each month. Rostov, Samara and Voronezh were each to receive more than 20,000 wounded a month, with 2,500 going to Perm ${ }^{-} .^{41}$ The planning set out the details of the railway routes that hospital trains were to take to transport casualties, identifying five routes by which wounded would arrive in Moscow. The general staff estimated that sixteen hospital trains would be needed to transport the wounded inside the Moscow evacuation district, with a further sixty six trains required to bring casualties from the front. ${ }^{42}$

While the general staff had set out the basic elements of its evacuation plan for casualties, much remained uncertain when war broke out. It very quickly became clear that, while the army had made very precise calculations about the number of casualties and how they should be treated, it had failed to move beyond its paper planning to ensure that the physical and human resources needed to implement its plans were in place. The Moscow city board expressed significant concerns about the ability of the city to cope with the scale of the task that it was expected to deal with. At its meeting on 28 July, the board set out the gulf that existed between its planned role and the current extent of provision for receiving casualties: while the city was expected to take at least 35,000 wounded men each month, the city board noted that Moscow hospitals had only a total of 3,500 beds available. At the same time, there had been no discussion of how to provide all the necessary equipment for treating the wounded, and the city board questioned the availability of basic medical supplies and linen. ${ }^{43}$

40 TsGAM, f. 179, op. 6o, d. 791, 1l. 35-36, Zhurnal predstavilelei gorodov i zemstv, prinadlezhashchikh $k$ Moskovskomu Evakuatsionnomu okrugu, po voprosam pomoshchi bol'nym i ranenym voinam, iulia 31 dnia 1914 goda.

${ }^{41} S^{\prime \prime}$ ezd gorodskikh golov, p. 7.

${ }^{42}$ TsGAM, f. 179, op. 6o, d. 1, 1. 22, 'Po evakuatsii ranenykh i bol'nykh v predelakh Moskovskogo okruga'.

${ }^{43}$ RGVIA, f. 12593, d. 1, 1l. 83-84, Zhurnal No. 1 soveshchaniia Moskovskoi Gorodskoi 
The rapid engagement of the Russian armies in East Prussia brought the plans for dealing with casualties into sharp focus. The first train carrying casualties arrived in Moscow on 6 August and within three days some 2,000 wounded men had been transported to the city. ${ }^{44}$ Within a few days there were reports of increasing numbers of trains arriving in Moscow, and the city authorities quickly realized that the situation was becoming very difficult. It was clear that the casualties had not been fed while they were on the trains bringing them to Moscow, while seriously wounded men were being transported in the same railway carriages as men who had only light injuries. Within two weeks of the first arrivals of casualties in Moscow, the position had become desperate. The city had insufficient places to house the wounded who were arriving each day, and by 18 August the 'huge and wholly unexpected flood of wounded men' meant that it was forced to take over the Brest night-shelter to house casualties, even though the building was entirely unsuitable for this purpose. Every vacant building at Moscow railway stations was requisitioned as temporary accommodation for the wounded and, even when all available railway buildings had been acquired to use for casualties, there were still insufficient beds for the men. On 23 August, the city board heard a report that the wounded would now have to lie on the floor in any vacant public building that could be found and that, therefore, as much straw as possible must be bought from the city's markets to provide basic bedding. ${ }^{45}$ Other cities in western Russia found themselves under similar pressure. The city of Kaluga received less than a day's notice of the arrival of more than 1,100 wounded men in mid-August and were told that a further 600 casualties would be sent there. The Kaluga mayor reported that the war ministry had refused to make any contribution to the costs of caring for the wounded and stated that Kaluga could take no more casualties. ${ }^{46}$ The Moscow city board declared on 18 August that the war ministry's evacuation plans had collapsed and that the city was having to take on tasks that were wholly unexpected. The board was angry that the ministry was incapable of fulfilling its legal duty to care for casualties, and that the city of Moscow was being placed in such a difficult position. ${ }^{47}$

The seriousness of the situation facing the army in dealing with casualties was all too obvious to observers. The head of the General Staff's evacuation section wrote on 10 August that:

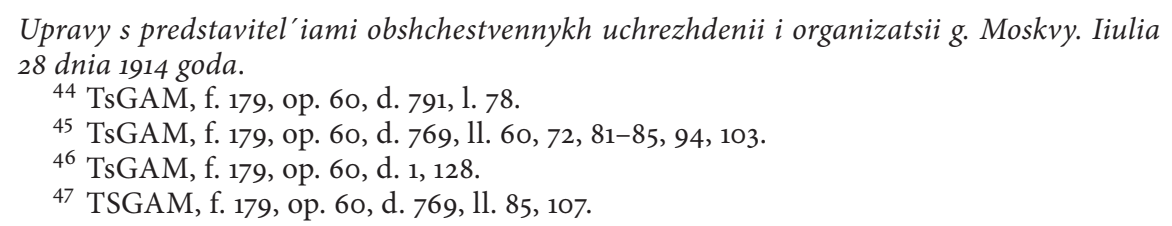


wounded and sick have started to arrive in the internal evacuation zone from the front. For the moment, numbers are small, but more men can be expected every day. The institutions of the internal evacuation organizations are however, completely unprepared to receive and accommodate casualties: distribution and regional evacuation points have not been set up; hospitals have not been organized; medical and other staff have not been selected and assigned to appropriate locations; the war ministry does not have proper hospitals for the long-term care of the wounded and the mobilization plans include no provision to establish or staff such institutions. It is plain that the internal evacuation organizations have neither the ability to receive casualties, nor to care for them. ${ }^{48}$

The desperate situation confronting the army was especially clear in the region just behind the front line: the head of the Vil'na railway police sent a telegram to his colleague in Baranovichi on 19 August reporting that 'more than 3,000 casualties have been crammed into Pinsk station over the past two days. Some men have not been fed for two days. The evacuation commission has not organized transport or food. Discontent is growing among the men'. Two days later on 21 August, the chief of the general staff sent a telegram to the quartermaster of the South Western front on 21 August noting that

yesterday a train filled with wounded troops from Kholm made up of fiftytwo goods wagons travelled from Baranovichi to Minsk without any food or medical supplies. The wounded have not been fed or had their dressings changed for several days and have no money. The commander-in-chief has ordered the most decisive measures be taken to deal with the medical organization of the army [...] for your information, the head of the medical section at the front-line is being replaced by a general.

The quartermaster replied that 'the mobilization timetable requires 100 field hospitals to be established in the South West reserve region. [...] So far, only fifty four hospitals have arrived. We are short of forty six field hospitals. The need for them is huge'. ${ }^{49}$

Newspapers reported on the pressures that the wounded placed on the empire's social fabric. During September 1914 Moskovskie vedomosti published a series of commentaries entitled 'The Wounded', noting on 3

48 'Raport nachal'nika evakuatsionnogo upravleniia GUGSh i. d. nachal'nika GUGSh, 10 avgusta 1914 g.', Sanitarnaia sluzhba, pp. 209-10.

49 Ibid., pp. 210-11. 
September that 'the most typical feature of Moscow life now is the wounded. [...] a sad and heart-rending landscape'.$^{\circ}$ The following week, the newspaper reported that 'there are now very many wounded in Moscow. All the public and private hospitals are overcrowded. Everyone is asking for the lightlywounded and convalescent to be moved elsewhere.. ${ }^{51}$ The Russian political and social elite took a keen interest in the treatment of casualties. The Dowager Empress Mariia Fedorovna wrote in her diary on 9 August that 'the Red Cross is behaving marvellously, in contrast to the war ministry which is doing precisely nothing to help the wounded' and she demanded that Grand Duke Nikolai Nikolaevich, the Commander-in-Chief, take urgent action to prepare a proper evacuation plan for the wounded..$^{52}$ Count Ivan Tolstoi, the Petrograd mayor, reported a conversation with a Moscow politician who 'painted a terrible picture of the condition of casualties in the old capital: there were now upwards of 35,000 wounded men there, but there were not enough hospital places for them, so many walk the streets in hospital gowns, asking for charity from passers-by' ${ }^{53}$ Sergei Mel'gunov, the former Kadet politician and prolific journalist, commented in his diary on the disorganization and lack of preparedness for dealing with the wounded. He recounted reports of fully-staffed hospitals that had no patients, while others had hundreds of wounded to care for, but only a handful of nurses. ${ }^{54}$ The organization of care for the wounded was in a state of extreme disarray and Mel'gunov noted that hospitals were short of bandages and clothing for their patients. His sister, Praskoviia Mel'gunova, wrote in her diary in September 1914 that the military hospital on Ekaterinskaia square had 600 patients, but only eight nurses and three doctors. Operations were being carried out without anaesthetic and 'there were cries of pain' throughout the building..$^{55}$ The chairman of the State Duma, Rodzianko, wrote to Grand Duke Nikolai Nikolaevich, expressing the concern of society about the disorganization of medical care for the wounded. The commander in chief responded to Rodzianko, recognizing the poor organization for dealing with the wounded and explaining that it was due to the very rapid engagement of Russia's troops in full-scale fighting along a front that was more than $700 \mathrm{~km}$ in length. Disturbed by the reaction to the chaos, Nikolai Nikolaevich instructed Prince P. A.

${ }^{50}$ Moskovskie vedomosti, 3 September 1914, p. 3.

${ }^{51}$ Moskovskie vedomosti, 10 September 1914, p. 4.

52 Dnevniki Imperatritsy Marii Fedorovny (1914-1920, 1923 gody), Moscow, 2005, p. 52.

53 I. I. Tolstoi, Dnevnik 1906-1916, St Petersburg, 1997, p. 546.

54 S. P. Mel'gunov, Vospominania i dnevniki, Moscow, 2003, p. 243.

55 'K zapisiam 1914-1916 gg. Otryvki iz dnevninka P. E. Mel'gunovoi', ibid., p. 281. 
Oldenburgskii, the newly-appointed head of the sanitary and evacuation department, to hold a meeting with Rodzianko and discuss with him what was being done and what would be done in the future to alleviate the situation. ${ }^{56}$

In these chaotic circumstances, Russia's local government institutions were able to stake their claim to play a major part in providing assistance to Russia's military casualties. The official report of a meeting of the Moscow zemstvo on 25 July included a vigorous rallying call to action:

with the first rumblings of the coming storm, and simultaneously with the shouts of victory, there will also be heard the groans of thousands and tens of thousands of men wounded and dying on the battlefield. It becomes, therefore, the duty of those who remain at home to strain every effort to render them timely aid. Those left at home should take up positions in regular battle array, so as to be ready to carry out quickly, promptly and efficiently the task of aiding the sick and wounded that will confront them and will probably assume gigantic proportions. Who, if not public institutions whose business is to provide for the needs of the people and who have had many years of practical experience in caring for the sick, with organized forces at their command, should undertake the task of uniting the isolated forces in this great work, which demands such complex organization? ${ }^{27}$

The collapse of the war ministry's plans to evacuate and treat casualties meant that there was an immediate need for Russia's local government institutions to provide assistance, especially in Moscow. The scale of the help needed was initially unclear: on 23 July the Moscow city board heard a report that Moscow hospitals could accommodate 1,600 casualties. ${ }^{58}$ However, when representatives from the Moscow evacuation district met on 31 July, it was reported that civilian patients had been discharged from hospitals where possible, so that the city now had 3,500 vacant beds, with the intention that this would rapidly rise to 10,000. Moscow University promised to take a further 600 casualties immediately and, could, in case of necessity, increase this to 2,000. The Moscow zemstvo offered up to 10,000 hospital beds, but it was clear that, even with these promises of

\footnotetext{
${ }^{56}$ A. B. Astashov, 'Soiuzy zemstv i gorodov i pomoshch' ranenym v pervuiu mirovuiu voinu', Otechestvennaia istoriia, 1992, no. 6, pp. 169-72, (p. 171).

57 Vserossiiskii zemskii soiuz pomoshchi bol'nym i ranenym voinam. Obzor deiatel'nosti Glavnogo Komiteta. 1 avgust 1914 - 1 fevral' 1915, Moscow, 1915, pp. 20-21.

${ }^{58}$ TsGAM, f. 179, op. 6o, d. 769, 1. 12.
} 
help, the total number of beds offered was likely to be less than half of what would be required. There was a recognition that the figures for casualties calculated by the war ministry were purely theoretical and that the actual numbers of wounded could be two or three times as many as the army had predicted. ${ }^{59}$ Two days later the Moscow city board estimated that the city might receive up to 50,000 casualties each month and appealed for every public organization - merchant associations, the Stock Exchange committee, gentry assemblies, trade associations and monasteries - to play a part in providing assistance. ${ }^{60}$ When the preparatory committee for the Union of Towns met on 3 August, it recognized the enormity of the task facing it. The new organization saw its immediate priorities as being to find premises to accommodate the wounded, establish hospitals, the evacuation of the wounded, coordinating the purchasing of supplies to provide medical care, organizing the sewing of linen, providing help to soldiers' families and collecting financial contributions to support its work. $^{61}$

The initial stresses of war were also felt in Russia's provincial towns and cities. The Viazma representative at the meeting of city mayors in early August noted how the task of caring for the wounded presented significant difficulties for his town of 100,000 people. Viazma needed new buildings to accommodate casualties, while it had a severe shortage of medical personnel. More problematically, the city was located in the area of Russia that was under military control and therefore public organizations were not permitted to play a part in evacuating and treating the wounded. Representatives from Voronezh, Nizhnii-Novgorod, Kaluga and Tver reported that their cities each lacked the financial resources to implement plans for evacuating and caring for the wounded, while the Kursk delegate noted that his city could fulfil barely one tenth of what was being demanded of it. ${ }^{62}$ Casualties were arriving in cities to the south west of Moscow from mid-August. In Orel, the provincial governor agreed with the Orthodox church to take over the spacious premises of the diocesan girls' school to accommodate wounded men, while the local military authorities provided a barracks building in the town of El'ets to take 1,000 casualties so that by

59 TsGAM, f. 179, op. 6o, d. 791, 11. 34-41, Zhurnal predstavilelei gorodov i zemstv, prinadlezhashchikh $k$ Moskovskomu Evakuatsionnomu okrugu, po voprosam pomoshchi bol'nym i ranenym voinam, iulia 31 dnia 1914 goda.

60 TSGAM f. 179, op. 6o, d. 769, 1. 16.

${ }^{61}$ TSGAM, f. 179, op. 60, d. 791, 1. 72, Zhurnal predvaritel'nogo komiteta po organizatsii obshc-gorodskogo vserossiiskogo s"ezda, 3 avgusta 1914 goda.

${ }^{62} S^{\prime \prime} e z d$ gorodskikh golov, pp. 28-33. 
the end of August the province was able to house 3,00o wounded men. ${ }^{63}$ At the same time, the Nizhnii-Novgorod mayor reported that the city had been unable to accommodate 300 casualties in zemstvo hospitals, as they were unprepared for such an influx of wounded and asked for proper communication between the various organizations involved in evacuating casualties. ${ }^{64}$

Russian local government acted quickly to provide help to military causalities. Immediately after the establishment of the zemstvo union was approved by the government, the union began to plan the way in which casualties could be distributed across Russia's provinces, making calculations for different numbers of wounded and working out the movement of hospital trains to evacuate men from the front line. By the middle of August the national zemstvo union had decided to equip fifty hospital trains to evacuate the wounded, although a shortage of suitable railway wagons meant that the trains could not be brought into immediate service. The war ministry, recognizing that its initial insistence on excluding public organizations from the war zone was untenable, asked for twenty trains to be sent to the front line. Each train would convey nearly 400 casualties and by late August the first zemstvo trains were at work. ${ }^{65}$ The union then began to identify suitable hospitals, initially using existing institutions. It was immediately clear that these institutions would not be adequate, and the union looked for any buildings close to both existing hospitals and to railway stations. By the middle of September, the Moscow zemstvo was able to report that it had almost 18,0oo beds available for casualties. The Moscow provincial zemstvo equipped four of its own hospital trains to move the wounded across the fifteen provinces of the Moscow region, and in the first five months of war the Moscow zemstvo was able to evacuate nearly 120,000 men. ${ }^{66}$

The work of evacuating casualties and treating their injuries revealed that Russia's soldiers needed much greater levels of assistance. The wounded had to be fed, and the two unions began to establish feeding stations at key points along the railway routes where hospital trains ran. As summer ran into autumn, the casualties required warm clothing and mayors in both Vladimir and Nizhnii-Novgorod reported that they had purchased winter clothes and footwear. The newly-established hospitals

${ }^{63}$ Belova, Pervaia mirovia voina, p. 132.

${ }^{64}$ RGVIA, f. 12564, op. 1, d. 22, 1. 3.

${ }_{5}$ Vserossiiskii zemskii soiuz pomoshchi bol'nym i ranenym voinam. Izvestiia glavnogo komiteta, 15 October 1914, pp. 14-15, 31.

${ }^{66}$ RGVIA, f. 12564, op.1 , d. 3, ll. 7-8. 
also required equipping and the Union of Towns began work to organize a central linen store, while it also sought to deal with the shortage of medical instruments by sending sample sets of instruments to provincial towns to show local manufacturers what was needed. Provincial cities each had their own needs: it was reported that Kiev required bathhouses for the wounded men, while Zhitomir needed basic first aid material and Viatka was short of linen. A report in autumn 1914 identified the serious situation facing men who had lost limbs as a result of their injuries and the Union of Towns agreed that a workshop should be established to manufacture prostheses. $^{67}$

Despite the level of detailed planning by the two unions in the first weeks of the war, the situation remained chaotic and confused. Moscow's position at the centre of the Russian railway network meant that it continued to receive the greatest number of wounded men. The city Duma tried to relieve the pressure on the city's hospitals by offering private individuals twelve rubles per month if they would take care of a lightly wounded man in their own homes. The Duma considered requisitioning private property to provide accommodation for the wounded, and it also faced a significant shortage of doctors and other medical personnel to treat casualties. Even when men recovered from their injuries, it was difficult to discharge them from hospital: many of the soldiers had inadequate clothing and by mid-September the Moscow city Duma had to limit the distribution of clothing to convalescent soldiers otherwise it would have no supplies for newly arrived men. To try to ameliorate the situation, the Duma proposed to organize a 'clothing collection week' in Moscow. Even when soldiers could be discharged from hospital care, the army was reluctant to accept them back into its ranks, as by September 1914 the army's own distribution points were overwhelmed and chaotic. ${ }^{68}$

The financial costs of providing such widespread care to the wounded were very substantial and the question of how the work of local government was to be funded was very high on the agenda for both the national unions and individual zemstva and city councils. The two unions made it clear to the Russian government that they could only provide support to the wounded if they received significant financial assistance from the national government. At the first meeting of the Union of Towns it was agreed to send a delegation to Petrograd to make it plain that, while Russia's cities were ready to use all the resources they could generate themselves by

${ }^{67}$ RGVIA, f. 12593, d. 46, 1l. 50, 63-64, 79.

${ }^{68}$ TsGAM, f. 179, op. 6o, d. 769 , 1l. 107-17, 145; d. 770, 1. 8. 
reducing their other activities and by seeking loans, they needed financial help from the government in order to carry out all the tasks that were needed. ${ }^{69}$ Brianskii, the Moscow mayor and chairman of the Union of Towns, travelled to Petrograd as soon as the organization had been established and had a sympathetic hearing from the government. On 12 August he met Goremykin, the chairman of the Council of Ministers, Maklakov, the Minister of Internal Affairs, Bark, the Minister of Finance and Krivoshein, the head of the agriculture department. The ministers promised financial assistance to the new organization, with one million rubles to be provided immediately and a further twenty million rubles once the union had produced detailed estimates of expenditure. ${ }^{70}$

Financial contributions also came from a wide variety of individuals and groups. Sergei Morozov, the Moscow businessman and art patron, donated 500,000 rubles to the zemstvo union and a further 200,000 rubles to the Union of Towns in August 1914 - and was received personally by Nicholas II and thanked for his contributions. The Petrograd city Duma board contributed 100,000 rubles to the union, while it also received donations in kind, including one of 500 bottles of wine. Funding also came directly from the military, with the Moscow army commander contributing 4,000 rubles towards the cost of clothing for casualties. By the end of August, the unions had gained a better idea of the scale of the financial resources needed to cope with the demands being placed upon them. They estimated that some 104 million rubles was required to assist with caring for casualties in the area of the empire outside the military zone: the provision of a single hospital bed cost 125 rubles, while the unions needed three million rubles to equip bathhouses, feeding stations and temporary barracks, and a further five million rubles was needed to spend on measures to combat the spread of infectious diseases and 1.3 million rubles for linen. The Moscow military commander was asked to provide a further 50,000 rubles to clothe regular soldiers who were being discharged; the Union of Towns estimated that they needed 40,000 winter coats, 50,000 hats and 40,000 pairs of boots. ${ }^{71}$ The Union of Towns held further meetings with ministers early in September, and the government repeated its promise to provide the necessary resources for the work of the unions.

${ }^{69}$ RGVIA, f. 12593, d. 1, 30-31, Zhurnal No 1 Komiteta Vserossiiskogo Gorodskogo Soiuza pomoshchi bol'nym i ranenym.

${ }^{70}$ RGVIA, f. 12593, d. 46, 1. 51.

${ }^{71}$ RGVIA, f. 12593, d. 1, 1. 229, 152, 238, 249, Zhurnal No 3 Komiteta Vserossiiskogo Gorodskogo Soiuza pomoshchi bol'nym i ranenym; Vserossiiskii zemskii soiuz pomoshchi bol'nym i ranenym voinam. Izvestiia glavnogo komiteta, 15 October 1914, pp. 8, 11. 
In the first six weeks of war, the Union of Towns received 3.6 million rubles as income, with more than eighty per cent provided by the government. At their meeting on 5 September, members of the union's executive committee wanted confirmation that the finance from the government was an outright grant and were assured that L'vov had seen minutes of a Council of Ministers meeting confirming this. ${ }^{72}$

Finance provided only one of the tensions that accompanied the establishment of the two national unions. There were reports of stresses at local level between urban authorities and local zemstva, and the national unions emphasized that it was important for the two sets of organizations to work together at local level in the same spirit of cooperation that was being displayed nationally. The Union of Towns executive committee stressed that this was the first occasion when two strong representative bodies were working together in Russia and that it was important not to damage the unions' reputation in the eyes of the government. ${ }^{73}$ The relationship between the new unions and the government was, however, much more difficult than the stresses between local bodies on the ground. Even though the government welcomed the work that the unions could do to help Russia's casualties and provided funding to the new organizations, it was very concerned that the new organizations would try to expand their area of activity. At the initial meeting between Brianskii and government ministers in mid-August, the government promised to instruct provincial governors to allow both local zemstva and city councils to hold congresses. In September the Ministry of Internal Affairs gave permission for a national congress of the Union of Towns, but it was very concerned about the union extending its area of activity and emphasized that the congress must not discuss topics that were outside its immediate remit, in particular, it must avoid the issues of assistance to soldiers' families and of food supply to Russian cities. ${ }^{74}$ The November meeting of the Council of Ministers that discussed the position of the two national unions received a report from Maklakov, the Minister of Internal Affairs, in which he expressed his concern at the establishment of 'such powerful public organizations' that stood outside the legislation governing the activities of individual zemstva and city Dumas. Maklakov wanted to impose tight controls on the unions,

${ }^{72}$ RGVIA, f. 12593, d. 1, 11. 260-61, Zhurnal No 4 Komiteta Vserossiiskogo Gorodskogo Soiuza pomoshchi bol'nym i ranenym.

${ }^{73}$ RGVIA, f. 12593, d. 1, 1. 236, Zhurnal No 3 Komiteta Vserossiiskogo Gorodskogo Soiuza pomoshchi bol'nym i ranenym.

${ }^{74}$ RGVIA, f. 12593, d. 1, 1. 270, Zhurnal No 4 Komiteta Vserossiiskogo Gorodskogo Soiuza pomoshchi bol'nym i ranenym. 
especially by subordinating their financial affairs to the regulations of the State Comptroller. The Council of Ministers, however, concluded that the temporary nature of the unions' work meant that their uncertain legal status did not pose an insuperable problem. The ministers did recognize Maklakov's concerns and, while they did not agree with all his proposals, noted that the State Comptroller already had the power to audit the unions' finances. The meeting did concur with Maklakov's proposal that local authorities should be able to insist on the dismissal of inappropriate individuals from service in the unions. ${ }^{75}$

These concerns about the views and character of the unions' employees resulted in the Department of Police's Special Section scrutinising the staff of the unions. In November 1914 the head of the army's evacuation service wrote to the Warsaw okhrana noting that he had received information that staff of hospital trains running between Warsaw and Vil'na were engaged in spreading revolutionary propaganda and requesting the police to investigate the train staff and observe their activity. Similar concerns were expressed by Danilov, the army's Quartermaster-General, who requested the help of the okhrana in combating 'systematic propaganda' being carried out on hospital trains. The police responded by sending undercover agents to work on hospital trains and attempted to carry out checks on each member of the staff of the trains. The police compiled detailed information on the staff of the Warsaw hospital train, but found it very difficult to identify each individual accurately, since information from different regional police departments was often contradictory. ${ }^{76}$ Nevertheless, two people working on the Warsaw hospital train did emerge from the okhrana files: Olga Brillantova, a doctor, had been arrested in March 1913 in connection with a student strike at the Women's Medical Institute and Mariia Iushina, a nurse, had been a member of the Vologda Socialist Revolutionary party and had been placed under police surveillance. Even placing a police agent on the train to conduct surveillance proved awkward, and could only be carried out in Moscow where each train's staff was assembled. The police proposed that all the staff of hospital trains should be registered and that anyone who the police identified as politically unreliable should be dismissed, while each train should carry a police informant as a member of its staff. ${ }^{77}$

75 'Osobyi zhurnal soveta ministrov, 25 noiabria 1914 goda', Osobye zhurnaly Soveta ministrov Rossiiskoi imperii. 1914 god., Moscow, 2006, pp. 552-53.

${ }^{76}$ Moscow, Gosudarstennvyi Arkhiv Rossiiskoi Federatsii (GARF), f. 102, OO, op. 244 (1914), d. 343 z. s., t. 1, ll. 1-9, 325.

77 GARF, f. 102, OO, op. 244 (1914), d. 343 z. s., t. 2, ll. 383, 469, 543. 
The establishment of the two national unions created immediate tensions with the government at both national and local levels. The unions came into existence very quickly in the first weeks of war when it became plain that the army's planning for dealing with casualties was wholly inadequate. The exigencies of a major European war exposed the weakness of the army's preparations for conflict very publicly: the chaotic scenes as thousands of wounded men were evacuated from the battle zone were obvious to much of Russian society. Moscow, Russia's second largest city and at the heart of the national railway network, was suddenly and unexpectedly transformed into the national centre for dealing with military casualties. In August and September 1914 more than 120,000 wounded men arrived in the city for treatment. The appearance in this great metropolis of clear evidence of the war being fought on Russia's western borders provoked mixed responses among the city's population. For many, the experience of war provoked a new sense of national unity. In October 1914 Moskovskie vedomosti reported on a sense of renewal among students and the intelligentsia, writing that 'we have found our common language [...] we have all recognized that we are Russian sons of a single great and indivisible Russia' ${ }^{78}$ The newspaper was keen to emphasize the way in which the war 'has drawn together our fragmented society ${ }^{79}$ and the widespread ways in which Russian society contributed to the care of military casualties provided clear evidence of the way in which war provided a sense of national purpose. An article in Russkoe slovo in early September described a visit by a correspondent to a Moscow friend who had taken in five wounded men to live in his apartment, accommodating three men in the sitting room and two in the study, with the owner himself now living in the kitchen. ${ }^{80}$ Organizations as well as private individuals contributed to the care of casualties: during September the press reported daily on the opening of new hospitals, with 240 beds in twelve hospitals opening on 18 September, including a twelve-bed hospital in the premises of the Solov'ev Religious-Philosophical Society and a further thirteen hospitals opening on 24 September, including a 30o-bed hospital in the Trekhgornyi brewery. ${ }^{81}$ When confronted in their own city with the evidence of the war, many Muscovites rallied to support their troops and provided very substantial resources to care for Russia's casualties. Among the goodwill towards the wounded men, however, was a recognition

${ }_{78}$ Moskovskie vedomosti, 17 October 1914, p. 1.

79 Moskovskie vedomosti, 1 October 1914, p. 3.

${ }^{80}$ Russkoe slovo, 2 September 1914, p. 4.

${ }^{81}$ Moskovskie vedomosti, 18 September 1914, p. 3; 24 September 1914, p. 3. 
of Moscow's unpreparedness to deal with the crisis that confronted it, especially with the onset of winter. ${ }^{82}$

The government was deeply ambivalent about the two unions. It recognized that the pressures of the war, and the failure of its own plans to deal with casualties, meant that it had to accept the help of local government institutions in evacuating and treating the wounded. Its own resources were insufficient for the task of dealing with hundreds of thousands of casualties, and it could not ignore the men's plight or delay evacuating and treating them. The Russian government was caught off-balance by the speed with which its armies suffered casualties in the first weeks of war, so that the two national unions were able to establish themselves without going through the normal protracted legal processes needed to form associations in tsarist Russia. The unions thus emerged in August 1914 without clear definitions of their sphere of activity and without having had the Ministry of Internal Affairs scrutinize their constitutions and rules. This gave them very considerable latitude as the war developed, especially when the military situation continued to worsen during 1915. Most of the men involved at the centre of the two unions were highly experienced political figures, whether in provincial zemstva, city councils or the national Duma and State Council. They were well versed in the intricacies of Russian politics in the post-1905 era and had an innate comprehension of the tensions that existed between the Russian government and political and social institutions. For them, the patriotic duty of aiding Russia's wounded troops provided an opportunity for a marginalized Russian political class to wield real authority.

The summer and early autumn of 1914 thus brought about a fundamental change in the structures of authority inside the Russian empire, as central government was forced to concede power to organizations that were outside its control and headed by men who, while part of the social elite, were largely inimical to the way in which Russia was governed. The commitment that social organizations demonstrated to the war effort did not represent a rapprochement with the government: the failings of the regime were laid bare as the chaos of the evacuation and treatment of Russia's casualties become all too evident during August and September 1914 and this only added to existing disillusionment with the government. The patriotism of the two national unions was national, and did not represent approval of the tsarist regime. The government naturally wanted to believe that the fervour in support of Russia's troops represented a real change in wider political

${ }^{82}$ Russkoe slovo, 21 September 1914, p. 5. 
attitudes, but its own discussions about the activities of the two unions indicated that it immediately saw these public organizations as presenting a threat to the power of the regime. For the men who established the two unions, the events of August and September 1914 served to reinforce their view of the government. They drew a distinction between commitment to Russia's national struggle in war and support for the government. The catastrophic way in which the regime dealt with the men who had been wounded in the service of Russia only served to heighten the alienation of the two unions from the regime. The foundations for the mutual mistrust between government and public organizations that was to erupt into open conflict during 1915 were laid in summer and autumn 1914 as trains full of wounded, hungry, and ill-clothed men arrived in Moscow's railway stations from the battlefront. 